\title{
MAGNA CARTA 1215 TO NORTH KOREA 2015: ADVANCING THE IDEAL OF LEGAL RESTRAINTS ON GOVERNMENTAL POWER*
}

\author{
The Hon Michael Kirby AC $C M G^{\#}$
}

\section{MAGNA CARTA 1215}

\section{OF TOSH AND METAPHORS}

On the $800^{\text {th }}$ anniversary of the reluctant acceptance of a charter of rights and obligations by King John of England in 1215, many books have been written, essays published and lectures given, examining the relevance of this step in the long constitutional history of England (if any) and for the world of today.

Some commentators have doubted any relevance. Lord [Jonathan] Sumption, a judge of the Supreme Court of the United Kingdom, and an expert in mediaeval English history, has rejected any significance in what sounds to Australian ears as a somewhat condescending remark. "High minded tosh", he called it. ${ }^{1}$ Geoffrey Robertson QC, of Doughty Street Chambers, London, via Epping in Sydney, expressed somewhat similar views, but more politely. ${ }^{2}$ Michael Beloff QC, in this journal, ${ }^{3}$ has traced every case of the past century in which Magna Carta had been cited to reach a conclusion that its actual contemporary relevance was small. Other

\footnotetext{
* Text for an address given at the University of Buckingham, 2 October 2015.

\# Hon LLD (Buckingham). Justice of the High Court of Australia (1996-2009); Special Representative of the Secretary-General of the United Nations for Human Rights in Cambodia (1993-6); President of the International Commission of Jurists (1995-8); Chair of the United Nations Commission of Inquiry on Human Rights Violations in the Democratic People's Republic of Korea (2013-2014).

${ }^{1}$ Lord Sumption, 'Magna Carta - Then and Now', address to the Friends of the British Library, London 9 March 2015.

2 Geoffrey Robertson QC, 'The Magna Carta Inheritance', address to the Public Library of New South Wales, Sydney 3 September 2015.

3 Michael Beloff, 'Magna Carta in the Twentieth and Twenty-First Centuries' [2015] 27 Denning Law Journal 1.
} 
writers and lecturers were willing to find a greater materiality in the Charter for the world of today. ${ }^{4}$

Self-evidently, if we seek to draw a direct line of causation between the charter of King John and contemporaneous realities, we will be deceiving ourselves. I am not aware of any serious observer who takes such a literalistic view of the considerations of history. Certainly, I do not. But those who perceive a link are generally thinking and writing in allegorical terms. They appreciate, as I do, a poetic or grand theme. It concerns the struggle of people with lesser power to claim rights against their rulers, who enjoy great power over their persons, property and happiness. If that larger view is taken, the dramatic circumstances in which the Magna Carta of 1215 was extracted from King John, becomes a kind of symbol for what was to follow.

Lord Scarman, reflecting on the way the new world order of universal human rights was built after 1945 pointed, correctly, to the predominant influence played in the language and practice of the United Nations Charter, the Universal Declaration of Human Rights and other human rights treaties, of Anglo-American lawyers. In the enormous power of the United States of America (and the United Kingdom) at the end of the Second World War, they took the lead in designing the institutions and laws for the world that would follow. Naturally enough, they were aware of the history by which English-speaking peoples had asserted their rights against successive rulers. In that history, Magna Carta was one of the means that advanced the idea that governmental power should be limited. And that the limits should be expressed in an instrument that might be invoked whenever the ruler forgot it or failed to recall how it was secured. It is in this sense that it is relevant today to start a journey to Pyongyang in North Korea from the meadow at Runnymede in England.

\section{EUROPEAN CHARTERS OF RIGHTS}

In an important case ${ }^{5}$ concerning the requirements of the Australian Constitution, Justice Isaacs (later Chief Justice and Governor-General of Australia), and a great lawyer and judge, declared that the Magna Carta of England was the "great confirmatory instrument...which is the ground work of all our Constitutions".

In one clause of the Magna Carta of 1215, Isaacs detected "three basic principles, namely, 1)... Every free person has an inherent individual right

\footnotetext{
${ }^{4}$ For example Anthony Arlidge and Igor Judge, Magna Carta Uncovered (Hart 2015).

${ }^{5}$ Ex Parte Walsh and Johnson; In Re Yeats (1925) 37 CLR 36, 79.
} 
to his life, liberty, property and citizenship; 2) His individual rights must always yield to the necessities of the general welfare at the will of the State; 3) The law of the land is the only mode by which the State can so declare its will."

Whilst Magna Carta (as will be shown) has been treated as fundamental, there were, before 1215, numerous instruments that declared the rights of subjects vis a vis their rulers. Many kings and nobles in the second millennium of the Christian era granted charters to their subjects and tenants in terms that were not dissimilar to the provisions of the Magna Carta of 1215 (MC 1215). ${ }^{6}$ Indeed, it has been suggested that the English Charter reflected the influence of Spanish predecessors. ${ }^{7}$ At about the same time as it was granted in England, in 1222, the King of Hungary granted a very similar charter. ${ }^{8}$ Moreover, even in England, the Charter of 1215 had a number of predecessors dating back before the Norman Conquest of 1066 to Anglo-Saxon times. The Norman Conqueror (William I) himself issued a "brief but stately Charter which is still preserved by the City of London", promising respect for the laws of "King Edward's day". ${ }^{10}$ William promised that "I will not endure that any man offer any wrong to you. God keep you." 11

When Henry I acceded to the English crown in 1100, his first act was to issue a formal charter, called the Charter of Liberties, promising to stop certain oppressive practices that had grown up. His reign coincided with conflicts in many kingdoms between national monarchs and the universal Church. At issue were the competing claims respectively of the Church and the King to select the leading bishops, often the most powerful officials of the kingdom. To some extent, this dispute in Henry I's reign was addressed in the Concordat of Worms in 1122.

Many of the greatest minds of the Middle Ages in Europe devoted their attention to this issue. It raised the nature of kingship, the authority of royal power and law, and the limits that should be placed on the might of

\footnotetext{
${ }^{6}$ Theodore Frank Thomas Plucknett, A Concise History of the Common Law (4th edn, London, Butterworths 1948) 25.

${ }^{7}$ Henry Altamira in Magna Carta Commemoration Essays, quoted Theodore Frank Thomas Plucknett, A Concise History of the Common Law (n 6) 25 n 1.

${ }^{8}$ Ibid 25; noting that it had been translated in André Sayous, Histoire Général des Hongrois (Athenaeum 1900) 116-121.

${ }^{9}$ William Stubbs, Selected Charters in ibid 13; Anthony Arlidge and Igor Judge, Magna Carta Uncovered (n 4).

${ }^{10}$ St Edward the Confessor, King of England (1031-1066).

${ }^{11}$ Theodore Frank Thomas Plucknett, A Concise History of the Common Law (n 6) 13.
} 
temporal rulers. ${ }^{12}$ In that dispute lay the seeds of contemporary conflicts between the claims made for international law and universal human rights (on the one hand) and the sovereign rights of nation states, later embellished by claims of democratic legitimacy which the international order often appeared to lack. ${ }^{13}$

The succession in England of Henry II, in 1154, saw the reconfirmation of Henry I's Charter of Liberties of 1100. Henry II's reign was one that witnessed great legal developments. Important for present purposes is the reminder that, well before the charter in 1215, English Kings had been voluntarily and involuntarily subscribing to charters, promising to respect pre-existing laws. In that sense, the events of 1215 were not unprecedented, either in England or in other European States.

\section{THE ENGLISH CHARTER OF 1215}

What was novel about the Charter of 1215 was the rebellious and dangerous circumstances in which it came about; the detail and particularly of the demands of the English nobles who extracted it from the King; and the radical means of enforcement to which the King was forced to agree. John was an energetic monarch. He travelled extensively throughout his kingdom attempting to modernise what we would now describe as his administration. However, he was ill-tempered: making enemies easily. His political objectives included reclaiming territories in France that he saw as belonging to his paternal lineage. For that purpose, he demanded taxes and other burdens from the leading families of England. They challenged these demands. The disagreement came to a head on 12 June 1215.

The leading barons met the King at Runnymede. John claimed indisposition by reason of gout. The barons would have none of this. They refused to wait on him in his privy chamber. When he was brought on a chair into their presence at Runnymede, they did not stand. Instead, they presented him with their Charter. They insisted that he seal it. He did so with ill grace. However, in the event, MC1215 was actually in force for only 9 weeks. Within that time, the King sent emissaries to Pope Innocent III in Rome seeking absolution from his promises, on the basis that his will had been coerced, contrary to his conscience. ${ }^{14}$

${ }^{12}$ Ibid 14-15.

13 Alferd Aman, The Democratic Deficit: Taming Globalization Through Law Reform (New York, NYU Press 2004) 133, 163.

14 Told in David Carpenter, Magna Carta (London, Penguin 2015); Anthony Arlidge and Igor Judge, Magna Carta Uncovered (n 4); James Clarke Holt, 
The Charter was written in Latin, in continuous sentences. Subsequently, it was divided into paragraphs (usually called chapters). These set out the obligations extracted from John. There were 61 such chapters in all. A number of them repeated clauses of the Charter of Liberties of Henry I. Some of the added chapters dealt with the regulation of the use of the forests. These were later to be hived off into a separate Forest Charter. It was when this happened in 1217 (to be described later) that the non-forest chapters were for the first time described as the Great Charter (Magna Carta) (MC1217) ${ }^{15}$ For the moment it is enough to quote the chief chapters of MC1215 that still have relevance to the issues I wish to explore. They were: ${ }^{16}$

“(17) Ordinary law suits ('common pleas') shall not follow the Royal Court around, but shall be held in a fixed place...

(39) No free man shall be seized or imprisoned, or stripped of his rights of possessions, or outlawed or exiled, or deprived of his standing in any way, nor will we proceed with force against him, or send others to do so, except by the lawful judgment of his peers or by the law of the land.

(40) To no one will we sell, to no one deny or delay right or justice.

...

(45) We will appoint as justices, constables, sheriffs or other officials, only men that know the law of the realm and are minded to keep it well."

The last mentioned chapter (45) dropped out of the later reaffirmations of the MC. So did another chapter, which was the most bitter pill of all for King John to swallow. This was the so called "security clause", in chapter 61. It obliged local county sheriffs throughout England to take an oath to

Magna Carta (CUP 2008); Nicholas Vincent, Magna Carta: The Foundation of Freedom 1215-2015 (2nd edn, Third Millennium 2015). See review of Dan Jones, Magna Carta, The Making and Legacy of the Great Charter (Head of Zeus 2014) by Frederick Mount, 'Back to Runnymede' (2015) 37 London Review of Books 15.

15 James Spigelman, 'Magna Carta in its Mediaeval Context' (2015) 89 Australian Law Journal 383, 385.

16 Mary Arden, 'Magna Carta and the Judges: Realising the Vision' (2015) 27 Judicial Officers Bulletin 49, reproduced from Mary Arden, Common Law and Modern Society: Keeping Pace with Change (OUP 2015); Originally published (2012) 10 The Judicial Review 419. 
the Charter and to procure the selection of local knights to afford an assurance that its promises would be obeyed. It created a council of 25 members with power to remedy any breach of the promises committed by the King. It authorised the council to seize the King's castles, lands and possessions and made a number of other provisions to prevent, or discourage, royal evasion.

Little wonder that, after attaching his seal to these provisions, John was described by one unsympathetic observer as "gnashing his teeth, scowling with his eyes and seizing sticks from the trees... and gnawing them to break them". ${ }^{17}$ The ink of the seal was not dry but John sent his petition to the Pope in Rome. Because John had settled his disputes with Rome and submitted to papal authority in order to secure his support, ${ }^{18}$ the result was rebellion. A message was sent to a French prince (later to be King Louis VIII of France) inviting for some barons to invade England and to assume the English Crown. He accepted the invitation and embarked. But, providentially, at that moment, John died and his son (Henry III) began his long reign (1216-1272). Wisely counselled by his Regent, ${ }^{19}$ John's successor reissued and confirmed the Charter in 1216. However, it was reduced from 63 to 40 chapters. The security clause disappeared never to reappear. Moreover, a new provision required that the King would not impose scutage without the "counsel of the realm". ${ }^{20}$ To the idea behind this promise may be traced the constitutional principle (as it later developed) that no taxation should be levied on those liable to tax, save by their acquiescence, signified in the legislature.

\section{LATER HISTORY OF MAGNA CARTA}

The infant King Henry III reissued the promises once again in a 1217 version, by this time known as Magna Carta. It was, on that occasion, not a concession of a weak monarch but a general statement of good governance promulgated on the new monarch's behalf, to confirm and

\footnotetext{
17 Anthony Arlidge and Igor Judge, Magna Carta Uncovered (n 4) 81. See also James Spigelman, 'Magna Carta in its Mediaeval Context' (n 15) 385.

${ }^{18}$ Including by the appointment of Stephen Langton as Archbishop of Canterbury after a five year delay. John not only paid homage to the Pope, acknowledging him as his feudal overlord. He also later took a vow as a crusader to further extend papal protection for his Crown.

${ }^{19}$ William Marshal, Earl of Pembroke. See James Spigelman, 'Magna Carta in its Mediaeval Context' (n 15) 386.

${ }^{20}$ A tax or levy on knights in substitution for military service. It was not finally abolished in England until 1660 (12 Car 2, c 24 (1660)).
} 
acknowledge the loyalty of those who supported the notions of governance that it contained. When he came of full age in 1225, Henry III once again reissued and confirmed the Magna Carta. This time it was authenticated by his own seal, rather than that of his Regent. One added chapter prohibited the grant of freehold land to the Church on condition that the donor be readmitted promptly as tenant. Any such arrangement, in the future, would result in forfeiture of the land to the Crown. Thus began the legislative response to tax avoidance schemes, forms of which are still with us. ${ }^{21}$

Henry III reconfirmed MC about a dozen times during his reign. Eventually he did so in a form that would bind in all his successors. ${ }^{22}$ Although every monarch in England who made great promises sometimes broke them, the existence of Magna Carta provided a criterion for criticism, civic discourse and occasional rebellion. Effectively, the many successive versions of the Charter meant that in England "the King is and shall be below the law". ${ }^{23}$ Eventually, the 1297 text became the definitive version in England when it was entered as the first item in the official "Statute Roll" of Edward I By this time, it was viewed as "restorative and demonstrative, not constitutive". It was expressing time honoured rules that pre-existed the legal text.

In the same way today, the Universal Declaration of Human Rights (and later human rights treaty law) is taken to express the pre-existing fundamental rights of all human beings that emerge out of their very nature. In theory, these are rights not granted by the instrument; simply recognised, often with provisions contemplating enforceability. The MC1215 was expressed in terms of a "grant" of rights by the King, issued on the advice ("counsel") of 11 ecclesiastics, 16 barons and unnamed (faithful subjects). This language of "grant" could conceivably contemplate the possibility of withdrawal or revocation. However, later, the permanent form of Magna Carta of MC1225 (and the settled form of MC1297) were different in two important respects. They extended the promises to all "free men" and spoke of the relevant "liberties" not merely as having been "granted" but as "given and granted". The additional word "given" suggested a free gift by the monarch; something that could perhaps not be revoked. ${ }^{24}$

${ }^{21}$ James Spigelman, 'Magna Carta in its Mediaeval Context' (n 15) 387.

${ }^{22}$ MC1237. See ibid 387.

${ }^{23}$ Frederick Pollock and Frederic William Maitland, The History of English Law Before the Time of Edward I (2nd edn, Cambridge 1911) 173. See James Spigelman, 'Magna Carta in its Mediaeval Context' (n 15) 387.

24 James Spigelman, 'Magna Carta in its Mediaeval Context' (n 15) 389. 
Summing up the essential features of the Magna Carta, viewed at the end of the thirteenth century in which John had first granted it, JJ Spigelman describes its essential ideas for the emerging strong system of centralised government in the English kingdom. These features were to contribute, in the centuries that followed, to the comparative political unity, economic prosperity; and institutional strength that were eventually to become the foundations of the largest empire that the world has seen: ${ }^{25}$

"First, the acts of the King were not simply personal acts. The King's acts have an official character and, accordingly, are to be exercised in accordance with certain processes.

Secondly, the Charters affirm, by their very nature and the circumstances of their issue and confirmation, the obligation of the King to consult the political nation on important issues.

Thirdly, the Charters restrict the exercise of the King's feudal powers - subsequently transmographied into prerogative powers in accordance with traditional limits and conceptions of propriety. Fourthly, the King cannot act on the basis of mere whim. The King is subject to the law and also subject to custom which was, during that period in the process of being hardened into [the common] law.

Fifthly, underlying [the] Charters is the proposition that the King [in the part]... had acted contrary to established custom, and to some degree, contrary to the law [thereby requiring repair].

Sixthly, the King must provide a judicial system for the administration of justice and all free men [were entitled to due process of law]."

\section{ENDURING IMPACT}

By the time of the Confirmation in MC 1297, it had passed into a generally accepted backdrop for the English law. Other practical steps were taken in England to strengthen the development of the judge-made common law. These grew, in part, out of the promise of MC 1215 that "common pleas" (or ordinary law suits) would not follow the Royal Court around, as in Anglo-Saxon and early Norman times, but would be held in a fixed place. This idea gave a measure of stability, predictability and institutional focus for the law-making machinery of the kingdom, essential to the growth of the rule of law and the encouragement of possessions and trade. Doubtless influenced by this development, in 1218, salaries were

${ }^{25}$ Ibid. 
introduced for the senior justices of England for the first time. Clearly, this move was intended to combat corruption. But it also had the consequence of improving the quality of the judges and promoting a permanent professional judiciary that would evolve, and eventually express, notions of independence and impartiality. ${ }^{26}$ The sharing of royal power through the King's Council was a response, in part, to a succession of infant monarchs needing regents. In part, it grew out of the obligations imposed on the King by Magna Carta to "seek counsel" on particular royal and administrative conduct.

During the reign of Henry III, a judge and writer, Henry de Bracton produced a remarkable book De legibus et consuetudinibus Anglie (On the Laws and Customs of England). He did this for the purpose of instructing the newly emerging judicial institution. ${ }^{27}$ Magna Carta, and the strength and stability that it contributed to governance in England, encouraged the grand design of expounding rationally the whole of the English law as it was known in the 1220s and 1230s. Such an encyclopaedic attempt would not be repeated for five centuries.

Sir Edward Coke was a highly influential judge who later reminded James I that he was under the law. But he also asserted that the judges could overturn Acts of Parliament that were contrary to "common right and reason". ${ }^{28}$ As a general proposition, this notion has remained controversial. ${ }^{29}$ But it was to be developed, in a later age, into more modest notions of judicial review including for constitutional validity, that came to be highly influential in federal countries. ${ }^{30}$

In consequence of Coke's views, and the impolitic fashion in which he expressed them, James I removed him from office as a judge. He spent seven months in the Tower of London on a charge of treason. His papers were confiscated. Complaints were made that he was attempting to give

\footnotetext{
${ }^{26}$ Ibid 395.

27 John H Baker, 'Bracton' in Alfred William Brian Simpson (ed), Biographical Dictionary of the Common Law (London, Butterworths 1984) 69, 70.

${ }^{28}$ Dr Bonham's Case (1610) 8 Co Rep 107, 118a; [77 ER 638, 652].

29 Durham Holdings Pty Ltd v State of New South Wales (2001) 205 CLR 399; [2001] HCA 7.

${ }^{30}$ Marbury v Madison (1803) 5 US 1 Cranch 137. Discussed Michael Coper, 'Marbury v Madison (1803)' in Michael Coper, Tony Blackshield and George Williams (eds), The Oxford Companion to the High Court of Australia (Melbourne, OUP 2001) 453. Applied in $R v$ Commonwealth Court of Conciliation and Arbitration; Ex Parte Whybrow \& Co (1910) 11 CLR 1.
} 
the judiciary "a superintendency over the government itself" ${ }^{31}$ However, at least Coke was not executed. Bereft of office he turned his attention to legal writings. These included the compilation of his Institutes of the Laws of England. They were to be highly influential in later generations, particularly in the United States of America when it separated from England after the Revolution that began in 1776.

Magna Carta did not figure strongly in Coke's writings. As a sign of those times, Shakespeare (writing a little earlier) did not even see fit to include reference to the execution and annulment of MC1215 when he wrote his History of King John. ${ }^{32}$ The real credit for the revival of knowledge about, and interest in, Magna Carta can probably be traced to the writings of Sir William Blackstone, more an a century after Coke. Blackstone's Commentaries on the Laws of England was influential because of two features. First, it was written in a grand style that was meant to be read by informed laymen, whereas Coke had basically written for lawyers alone. Secondly, it coincided exactly with the loss of the American colonies and the severance of their link to the English judiciary. After that severance, more than was the case in England, Australia and continuing colonies, Blackstone's works served as the basis of legal education. ${ }^{33} \mathrm{He}$ was a strong advocate for what he saw as the checks and balances of English constitutionalism.

In Blackstone's story of the constitutional history of England, Magna Carta, the Protestant Reformation, the ultimate ascendancy of Parliament (that led to the execution of Charles I); the Glorious Revolution of 1688; and the Bill of Rights that followed, were all presented attractively as the causes that produced "a constitution with perfect checks and balances", by the time of the publication of his fourth volume in $1769 .{ }^{34}$ His encomium on the carefully calibrated limits upon governmental power was not only useful in the follow-up to the American Revolution. In a real sense, Blackstone described the features of constitutionalism that had attracted

\footnotetext{
31 Attributed to Lord Ellesmere. See John H Baker, 'Sir Edward Coke' in Alfred William Brian Simpson (ed), Biographical Dictionary of the Common Law (n 27) 117.

32 A point noted by James Spigelman, 'Magna Carta in its Mediaeval Context' (n 15) 383, who claims that Victorian theatre proprietors added a 'Runnymede scene' to repair Shakespeare's inadvertence.

${ }^{33}$ Gareth Jones, 'Sir William Blackstone' in Alfred William Brian Simpson (ed), Biographical Dictionary of the Common Law (n 27) 57.

${ }^{34}$ Ibid 61.
} 
the American colonists and inspired them to write their own Constitution, expressing a form of government that enshrined checks upon power. ${ }^{35}$

Chief amongst the checks were protection for a strong judiciary; incorporation of basic rights; and acceptance of the judicial umpire in any clash between the branches of government. Blackstone's text afforded the most elaborate history on Magna Carta. It was full of references to primary sources. Suitably enough, in an engraving from the author's portrait of 1775 by Thomas Gainsborough which accompanied the publication of his Commentaries, the seal of King John is clearly shown in a folded document in his right hand, intended to represent "an original Magna Carta". ${ }^{36}$ It is given pride of place over the Commentaries, that appear in the author's left hand.

The idea of a super-constitutional instrument such as Magna Carta not only encouraged the American revolutionaries to fashion a written constitution that prevailed over all other laws. It also affected the dominions and erstwhile dominions, of the British Crown as they adopted their post-colonial written constitutions: Canada in 1868. Australia in 1900. South Africa in 1910. The Irish Free State in 1923. Eventually, the same movement spread to non-settler countries beginning with India in 1950. As the years passed, many countries in the "new Commonwealth" witnessed the invocation of the Magna Carta idea.

In India, for example, a question arose as to the ambit of the express power under the Indian Constitution to amend the text of the document. Was every provision subject to formal amendment? Or were some provisions to be taken as sacrosanct: so fundamental to the overall design that they could not be altered by a mere voting majority? The question presented in India was whether Parliament, by the facility of amendment, enjoyed the constitutional power specifically to abridge the stated fundamental rights. In Golak Nath's Case ${ }^{37}$ a majority of the Supreme Court of India concluded that there were limits on the amending power.

35 Ian Doolittle, 'William Blackstone and William Prynne: An Unlikely Association?' in Wilfred Prest (ed), Blackstone and His Commentaries: Biography, Law History, (Oxford, Hart Publishing 2009) 56.

${ }^{36}$ John H Baker, 'Iconography, Likenesses, Portraits and Engravings' in Wilfred Prest (ed), Blackstone and His Commentaries: Biography, Law History (n 35) 229, 232. See also Wilfred Prest, 'Images, Statues and Stained Glass' in Wilfred Prest (ed), Blackstone and His Commentaries: Biography, Law History (n 35) at 238, 239 who describes a statue by John Bacon in the Codrington Library, All Souls' College, Oxford. Another statue appears in Washington DC.

${ }^{37}$ IC Golak Nath v Punjab (1967) 2 SCR 762; (1967 ASC 1643). See Also Kesavananda $v$ Kerala (1973) ASC 1461; (1973 supp SCR 1). 
That great judge, Justice Khanna, concluded that the amending power could not do away with such fundamental promises as the basic structure or framework of the Constitution: such as the republican nature of the state; obedience to the rule of law; and availability of judicial review. However, the fundamental rights provisions were held to fall outside this protected zone. Justifying this approach, the respected Indian jurist, H.M. Seervai, in his great text, Constitutional Law of India, wrote:

“... [T] he possession of power [to amend] was one thing, its exercise another. In theory, the British Parliament possessed the power to repeal great charters of liberty like the Magna Carta (1215), the Bill of Rights (1688) and the Act of Settlement (1700) as easily as it could repeal a Dog Act, but these great charters have remained unchanged." 38

A "fundamental" rule of constitutionalism may be stated as in Magna Carta. Yet, over time, ideas change and even "fundamentals" expressed in earlier times need alteration and renewal. Ultimately, the power over the content of law (including constitutional law) must generally rest with the people who are governed by that law. The people, or their representatives, must enjoy the last say.

\section{MAGNA CARTA GLOBAL}

The text of Magna Carta was not, as such, generally incorporated as equivalent to statute in the far flung colonies of the later British Empire. However, many of the basic principles expounded in the Charter profoundly influenced the thinking of the rebels who overthrew British rule in North America. Particular ideas of the MC1215 were influential in the language of several clauses of the United States Constitution.

Thus, the establishment of a permanent judiciary, sitting in fixed places and not itinerant (MC1215 c 17), is expressly reflected in the design of Article III of the United States Constitution. The specific prohibition on the seizure and imprisonment of persons and the violation of their rights or possessions (MC1215, c 39) is reflected in Amendment VI of the United States Bill of Rights: providing for trial by jury in criminal proceedings and, in Amendment VII, for civil proceedings and respect for the rules of the common law. The promise that justice would not be sold, denied or delayed (MC1215, c 40), is reflected in the right to

38 Hoemasji Maneckji Seervai, Constitutional Law of India - A Critical Commentary (3rd edn, Bombay, NM Tripathi 1996) 3115. 
speedy and public trial expressed in Amendment VI of the United States Bill of Rights. The promise of knowledgeable and honest judges and officials (MC1215 c 45) is reflected in Article II sec 1 of the United States Constitution. The retention of the residual powers to the people (in Amendments IX and X) of the United States Bill of Rights reflects the idea of restrictions on the plenitude of royal powers throughout Magna Carta. So does the notion, central to the United States Constitution (and others that later followed it), that governmental power is subject to the constitution, which all must obey and whose benefits and liberties all may enjoy.

Subsequent national constitutions in former British colonies and dominions, copied aspects of both the United States and British constitutional arrangements. The Australian Constitution, like the Canadian earlier, was a "successful combination of the British system of parliamentary government containing an executive responsible to the legislature with American federalism". Federalism itself is a system of divided and limited powers, springing ultimately from an idea central to divided powers, of Magna Carta.

In many British colonies, imperial legislation expressly provided for English statues to apply, unless the statute was not suitable to local conditions $^{39}$ or where the imperial statute made it plain that its terms were intended only to apply in what later became Great Britain and Ireland. ${ }^{40}$ The theory was that British settlers took the common law with them to the British colonies. ${ }^{41}$ That legal system, its doctrines and principles, were described as the "inheritance of the British race, and as such they became the common law of Australia". ${ }^{42}$ Magna Carta, certainly after MC1297, was admitted to the "Statute Roll" of England and was treated in some colonies as equivalent to imperial legislation. Yet like other such legislation, it could usually be overridden by valid colonial statutes and certainly by later imperial statutes and Acts of the legislature, as long as they were passed in accordance with the "manner and form requirements" prescribed. ${ }^{43}$ Many of the detailed provisions of Magna Carta were not "suitable to the conditions" of the colonies, necessarily established five

39 See eg Australian Courts Act (9 Geo IV, c 83 (Imp)). Cf Mitchell v Scales (1907) 5 CLR 405 (Griffith CJ) and (Barton J).

${ }^{40}$ Jolly v Suti (1899) $1 \mathrm{~N}$ and S 143 (Supreme Court Tasmania); Glasson v Egan (1866) 6 SCR (NSW) 85.

${ }^{41}$ Skelton $v$ Collins (1966) 115 CLR 94.

${ }^{42}$ Ibid (Windeyer J); See also $R v$ Maloney (1836) Legge 74 (NSWFC).

${ }^{43}$ Harris $v$ Danes (1885) 10 App Cas 279; $R$ v M'Carthy (1873) 4 AJR 155 (Vic FC). 
and more centuries later. However, concerning the principles of general importance, the common law would usually treat them as inherited and binding principles of law of general application.

The bias of the common law against arbitrary official intrusion upon the person or property of an individual and the centrality of access to the law to vindicate rights has been vigorously upheld by the courts in commonwealth countries centuries after Magna Carta was written: excepting only where valid legislation provided to the contrary. ${ }^{44}$ Sometimes, for the removal of doubt, local legislatures have enacted laws to make it clear that Magna Carta in particular chapters is, still to be treated as part of the local law unless clearly and expressly overridden by a local statutes. ${ }^{45}$

Nevertheless, for the most part, the Great Charter operates where it does today, as a symbol of large constitutional principles: limited governance; legal control over the ruler; responses to abuses of power; obedience to the rule of law; access to independent, professional judges; observance of divided and separated governmental powers; and respect and obedience to the judge-made common law. A society living under these principles is different from other societies in the world today. Especially, it is very different from the society that has emerged in the Democratic People's Republic of Korea (DPRK), to which I now turn.

\section{NORTH KOREA 2015}

\section{MANDATE OF THE COI}

It is a long way in time and space from Runnymede in the England of King John, in 1215, to Pyongyang in the time of Kim Jong-un, in 2015. Yet parallels exist between these times and places that need to be noticed.

King John was the comparatively recently enthroned monarch of England. His family had entered that kingdom earlier, accompanied by a large armed force from a then much more powerful and influential overseas kingdom, France. The family overthrew the local leaders with the foreign help. The ordinary people still dreamed nostalgically of an earlier, purer kingdom. Like King John, Kim Jong-un is a highly autocratic ruler. Kim causes opponents to be charged with treason and executed. He has

\footnotetext{
${ }^{44}$ A v New South Wales (2007) 230 CLR 500; [2007] HCA 10. See also Kuru v New South Wales (2008) 236 CLR 1, 6 [12]; [2008] HCA 36; New South Wales v Ibbitt (2006) 229 CLR 638; [2006] HCA 57.

45 See eg Imperial Acts Application Act 1984 (Qld), s 5 and sch 1 (Preserving Magna Carta 1297).
} 
resisted demands for the improvement of his regime. He abhors challenges to his power.

In the case of Kim Jong-un, the immediate pressure for change in his regime came not from a council of local personalities but from a Council comprising representative of the entire world: the Human Rights Council (HRC) of the United Nations. On 21 March 2013, the HRC, in virtual unanimity, proceeded to establish a mechanism to call Kim Jong-un to conform with basic principles of justice, good governance and universal human rights. ${ }^{46}$ In consequence of the HRC's resolution, a Commission of Inquiry (COI) was set up to investigate "the systematic, widespread and grave violations of human rights" in North Korea. The formal title of the country over which Kim Jong-un presides, as Supreme Leader, is the Democratic People's Republic of Korea (DPRK). However, as the COI was to discover and report, it is neither a democratic country with free and fair elections; nor one that engages its people in their own governance; nor does it have the hallmarks of a modern republic. Instead, it is, and was, a closed land, often described as a "hermit kingdom". It is like no other land in today's world - an absolute monarchy where a form of worship of the ruler is obligatory. The chief features of the country are set out in the ultimate conclusions of the COI: ${ }^{47}$

"80. Systematic, widespread and gross human rights violations have been and are being committed by the [DPRK] its institutions and officials. In many instances, the violations of human rights found by the [COI] constitute crimes against humanity. They are not mere excesses of the State; they are essential components of a political system that has moved far from the ideals on which it claims to be founded. ...

81. [DPRK] displays many attributes of a totalitarian State: the rule of a single party, led by a single person, is based on an elaborate guiding ideology that its current Supreme Leader refers to as "Kim Il-sungism - Kim Jong-ilism". Supressing all political and religious expression that question the official ideology, and tightly controlling citizens' movement and their means of communication with each other and with those in other countries. $\cdots$

\footnotetext{
${ }^{46}$ UNHRC Resolution A/HRC/Res/22/13.

${ }^{47}$ UN/A/HRC/25/63/[80]-[83]. See also Commission of Inquiry on Human Rights in the Democratic People's Republic of Korea (COI) Report A/HRC/25/CRP.1, 365-366 [1211]-[1214].
} 
82. The state's monopolisation of access to food has been used as an important means to enforce political loyalty....

83. The keystone to the political system is the vast political and security apparatus that strategically use surveillance, coercion, fear and punishment to preclude expression of any dissent. Public execution and enforced disappearance to political prison camps serve as the ultimate means to terrorise the population into submission. ... [T] he authorities engage in gross human rights violations so as to crack down on "subversive" influences from abroad. ... Persons who are forcibly repatriated from China are commonly subjected to torture, arbitrary detention, summary execution, forced abortion and other forms of sexual violence."

In light of these findings, the COI declared that the human rights situation in DPRK was "intractable" and that an effective response was imperative. ${ }^{48}$ It made a long series of recommendations, including many addressed to DPRK itself, calling on it to: ${ }^{49}$

"Undertake profound political and institutional reforms without delay to introduce genuine checks and balances upon the powers of the Supreme Leader and the Workers' Party of Korea; such changes should include an independent and partial judiciary, a multi-party political system and elected people's assemblies at the local and central level that emerged from genuinely free and fair elections; reform of the security sector... limiting the functions of the Korean Peoples' Army for defending the nation against external threats; and dismantling the State's security department [placing] the Ministry of Public Security under transparent democratic oversight."

\section{DETAILED REPORT}

The report of the COI responded to the nine point mandate given to it by the HRC. It began with a history of the establishment of a separate state in the northern half of the Korean Peninsula after $1945 .{ }^{50}$ That division was imposed upon the Korean people by foreign nations. It terminated a

\footnotetext{
48 Ibid 16 [86].

${ }^{49}$ Ibid 367 [1220(a)].

${ }^{50}$ Ibid 21-22 [95].
} 
long period of unified, centralised government, including during the years 1911-45 when Japan suppressed the independence of the Korean State and ruled it as a colony. ${ }^{51}$ After removal of the Japanese in 1945, the first Supreme Leader, Kim Ill-sung was imposed on North Korea by the then Soviet Union. He established the Supreme Leader system (suryong), modelled on Stalinist principles. ${ }^{52}$ He consolidated governmental power under the direction of his family. When he died in 1984, he was succeeded by his son, Kim Jong-il. ${ }^{53}$ The second Kim instituted a regime fully dependent on the military. It proceeded to develop a huge army and nuclear weapons with long-range missiles ${ }^{54}$ Upon the death of Kim Jongil in December 2011, dynastic succession passed immediately to Kim Jong-un. Shortly before, he and his aunt, Kim Kyong-hui, were promoted to four star generals, although neither had any real military experience. ${ }^{55}$ Their appointments were not ceremonial.

In December 2013, an uncle of the Supreme Leader, Jang Song-thaek, (earlier described as the Supreme Leader's "control tower" such was his role to guide the Leader), was taken under guard from a Politbureau meeting; summarily tried by a military tribunal; and executed. ${ }^{56}$ There have been many other recent reports of executions of high officials of the DPRK. ${ }^{57}$ The country that emerges from these reports is a violent and dangerous place of royal whims and fancies. In that respect it is not unlike the kingdom over which King John ruled before his encounter at Runnymede.

\section{FEATURES OF COI REPORT}

The ambit of the report of the COI on DPRK is considerably wider than the focus for which Magna Carta is now taken to stand, particularly respect for the rule of law (MC1215, c 17); protection of deprivation of rights and possessions and outlawry or exile (MC1215, c 39). Provision without delay or denial of rights and justice (MC1215, c 40); and establishment of settled courts and officials (MC1215, c 45). Thus,

\footnotetext{
${ }^{51}$ Ibid 27 [110]-[128].

52 Ibid 34 [129]

${ }^{53}$ Ibid 36 [134].

${ }^{54}$ Ibid 40 [143]-[148].

55 Ibid 41 [149].

${ }^{56}$ Ibid 43 [157].

57 'North Korea Vice-Premier Executed for Talking Back' The Australian (13 August 2015) 9. Reporting also alleged executions of Choe Yong-gou, reportedly killed in July 2015 and former Defence Minister Hon Yong-chol.
} 
chapters of the COI report deal with violations of thought and expression ${ }^{58}$ violations of freedom of movement and residence, ${ }^{59}$ violations of the right to food $;^{60}$ and crimes against persons living peacefully in foreign countries through abduction. ${ }^{61}$

Important sections of the report of the COI deal with the intrusion of the State in DPRK into matters of religious belief. ${ }^{62}$ Magna Carta did make provision for the status of religion in England. But in keeping with the approach in those feudal times, the only real freedom of religion was that of the Lord, whose subjects were obliged to conform to his beliefs. Nevertheless, the first article in the MC of 1215, later confirmed in 1225 and 1297, signified respect of the King for the Church, which was viewed as the "Holy Mother" of the Christian religion (MC1215 c 1):

"1. In the first place we have granted to God and by this our present charter have confirmed, for us and our heirs in perpetuity, that the English Church shall be free, and shall have its rights undiminished and its liberties unimpaired."

The picture of denial of religious freedom in DPRK is recounted in detail in the COI report. It describes a state where one of the four great freedoms of Franklin D. Roosevelt (the right to worship God in the way desired) is denied. Where, even on DPRK's own statistics, religious adherence has dropped from $23 \%$ of the population at the time of partition in 1945 to less than $1 \%$ today), with much testimony of persecution. The COI was uncertain as to whether this dramatic fall was because of the murder of religious adherents or simply a reaction to hostile State policy.

More to the point, several sections of the COI report illustrate the arbitrary interference in personal freedom, seizure of possessions; proceeding against others by force; and the absence of legal regulation over officials in DPRK. In particular, this is demonstrated in the sections of the COI report that deal with discrimination on the basis of a stateassigned social class (Songbun), gender and disability. ${ }^{63}$ Restrictions on the right to move freely in and out of the country and effective systems of outlawry and exile in the extensive system of arbitrary detention camps; systems of torture; public and other executions; enforced disappearances;

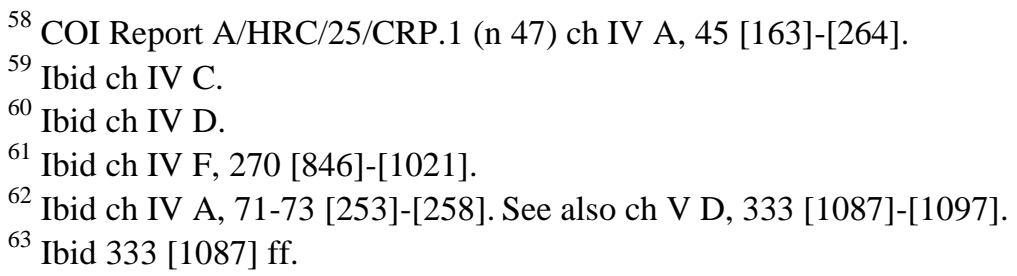


and removal of entire families into political prison camps. ${ }^{64}$ The camps in particular, remove suspected persons (and their families) into harsh and isolated conditions where work is arduous and food is scarce. ${ }^{65}$

Although DPRK has denied the existence of such detention camps, they were described in compelling detail by witnesses before the COI. Moreover, they are confirmed by precise satellite images. They certainly exist. They entail crimes against humanity. They are outside effective supervision in the ordinary prison system. ${ }^{66}$ They are not under the control of independent courts. They represent forms of forced labour amounting to enslavement. ${ }^{67}$ They constitute a "vast prison system [with] inhumane acts which follow regular patterns that victimise tens of thousands of inmates at any point in time." ${ }^{, 88}$

The COI was unconvinced that there were, in DPRK, any independent courts, judges or officials who could enforce accountability for the crimes and wrongs described in its report. The COI acknowledged that in other places $^{69}$ a partly international and partly national tribunal had been created to investigate and establish accountability for the wrongs found to have occurred. ${ }^{70}$ The COI on DPRK went on: ${ }^{71}$

"[T]hese models rely on the consent of the State concerned. Even if the DPRK were to provide such consent, the Commission takes the view that, in the absence of profound reforms to the DPRK's political and justice system, any DPRK judges designated to participate in such a high court would lack the impartiality and independence to carry out criminal trials that would likely involve any very senior officials as defendants."

The elements of stable courts made up of judges or like officials, who know the law and are minded "to keep it well" (MC1215, c 45) is absent from the DPRK. This is why the COI recommended referral of the case of DPRK to the Security Council of the United Nations. That body has the power, under the Rome Statute, to refer the case of DPRK to the

\footnotetext{
${ }^{64}$ Ibid 74 [265]-[354].

${ }^{65}$ Ibid 208 [693]-[845].

${ }^{66}$ Ibid 330 [1008]-[1086].

${ }^{67}$ Ibid 332 [1078].

${ }^{68}$ Ibid 333 [1083].

${ }^{69}$ Eg Cambodia and Sierra Leone. See [1673] fn.

${ }^{70}$ COI Report A/HRC/25/CRP.1 (n 47) 362 [1202].

${ }^{71}$ Ibid 361[1201.1].
} 
International Criminal Court (ICC), even though DPRK is not itself a party to the Rome Statute.

Several sections in the COI report also portray a country that has very grave policies and practices of discrimination against women. Women are often the citizens of DPRK who have first sought refuge, food and work in China. ${ }^{72}$ Attitudes of racial purity in DPRK lead to severe discrimination against women who come from China pregnant, or with children fathered, by Chinese men. ${ }^{73}$

The position of women in Norman England was also greatly disadvantageous at the time of Magna Carta. However, there were provisions in MC1215 which afforded a measure of respect for women's rights which was enlightened for its time. Thus it was provided: ${ }^{74}$

"Ch 7: After her husband's death, a widow shall have her marriage portion and her inheritance at once and without any hindrance; nor shall she pay anything for her dower, her marriage portion or her inheritance which she and her husband held on the day of her husband's death; she may stay in her husband's house for 40 days after his death, within which period her dower shall be assigned to her... No widow shall be compelled to marry so long as she wishes to live without a husband..."

Magna Carta contained, in its successive iterations, important protections for the customs of the City of London and for merchants and free trade. ${ }^{75}$ The freedom of persons to move between classes was greatly restricted by the feudal system in operation when Magna Carta was sealed. However, inflexible social regulation by reference to birth and class has disappeared today in most parts of the world. It is inconsistent with universal human rights. Yet forms of feudal control have been imposed in the DPRK by the State-assigned social class system

\footnotetext{
72 Ibid 118 [417] (describing the interrogation of women detainees); ibid 122-126 [424]-[428] (forced abortion); and ibid 132-139 [485]-[471] (female trafficking). ${ }^{73}$ Ibid 140-141 [474]-[476].

${ }^{74}$ Quoted in Tony Blackshield and George Williams, Australian Constitutional Law and Theory: Commentary and Materials (5th edn, Federation Pr 2010) 44, Magna Carta (The Great Charter) of 9 Henry 3 (1225) as confirmed by 25 Edw.1 (1297) quoted in [2.6] 42-43. However, limits were imposed on acting on the testimony of a woman. See MC 1225, ch 34.

75 Ibid 30 (freedom to leave and enter England) (ibid 44), ch 37 (customs and liberties).
} 
(Songbun). This was devised by Kim Ill-sung. ${ }^{76}$ Indeed, the implementation of Songbun was attributed to a purge of rivals of Kim Illsung. ${ }^{77}$ It is difficult to move to a higher social class. Yet it is less difficult to move down the ladder. The system appears to have some similarities to the fixed inherited social status that existed in feudal Korea. It has been strongly imposed in DPRK by the regime, as a method of social and economic control. There is now no equivalent social system in the Republic of Korea (ROK) (South Korea).

\section{COI FOLLOW-UP}

The COI report on the DPRK was approved and adopted by the Third Committee of the General Assembly of the United Nations, reflected in a strong vote. ${ }^{78}$ It was then transmitted to the plenary session of the General Assembly. This also adopted it with a strong vote that reached across geopolitical regions. ${ }^{79}$ Then, in accordance with the recommendation of the COI, ${ }^{80}$ two important follow-up proposals were accepted by the United Nations.

First, the General Assembly transmitted the COI report to the Security Council of the United Nations. The COI had recommended that the United Nations should refer the situation in DPRK to the ICC "for action in accordance with that court's jurisdiction." Secondly, the Office of the High Commissioner for Human Rights (OHCHR) implemented the recommendation of the $\mathrm{COI}$ that a field structure should be established in ROK "to help to ensure accountability for human rights violations in [DPRK], in particular where such violations amount to crimes against humanity." $" 81$

The placement of the recommendations of the COI before the Security Council was itself a step unusual for the United Nations system. Generally, the Security Council avoids direct involvement in human rights

\footnotetext{
${ }^{76}$ COI Report A/HRC/25/CRP.1 (n 47) 74 [265]. This is incompatible with the Universal Declaration of Human Rights 1948, art 2 and ICCPR/ICESCR, art 2; also Convention on the Elimination of all Forms of Discrimination Against Women 1979, art 1.

${ }^{77}$ Ibid 76 [273]. The COI recommended an end of discrimination based on social class. See ibid 368 [1220(h)].

78 Resolution of the Third Committee: United Nations, A/RES/69/188, (18 December 2014).

${ }^{79}$ Resolution of the General Assembly: United Nations, A/RES/60.1.

${ }^{80}$ COI Report A/HRC/25/CRP.1 (n 47) 370 [1225(a)].

${ }^{81}$ Ibid 371 [1225(c)].
} 
issues. However, a procedural resolution was adopted by the Council in December 2014, placing the issue of DPRK on the agenda of the Security Council. ${ }^{82}$ It will remain on that agenda at least for the next three years. That resolution was also adopted by a strong vote of the Council. ${ }^{83}$ The presence of the subject matter on the agenda of the Security Council means that it can be raised at short notice, by any Council member, including to consider referral to the ICC or, as the COI proposed, to "adopt targeted sanctions against those who appear to be most responsible for crimes against humanity." 84

The DPRK has not so far acquiesced in any action demanded by its critics. Its response so far has been like the reaction of King John to the Magna Carta. It has remained belligerent, hostile and uncooperative with the UN Human Rights system. Furthermore, in more recent times, it has stepped up hostile military action; entered into a "wartime state" to be fully "battle ready" to "launch surprise operations"; and engaged in incidents constituting the worst escalation of hostilities between the Korean states since $2010{ }^{85}$

A number of conciliatory gestures offered by DPRK during a "charm offensive" in 2013 and early 2014, designed to avoid referral of its record to the Security Council, were immediately withdrawn once the Security Council added the issue of human rights in DPRK to its agenda. The possession of weapons of mass destruction; the recent and current political and military posture; and the repeated incidents of violence against its own former elite, present the spectacle of a country that is very dangerous for its own people, to its neighbours, to the region and (through the risks of nuclear accidents or detonations) to the environment of the planet.

It is this grave escalation of danger that presents the urgent need for strong action to implement the COI report. But how will that action come about? Can a Runnymede moment be created for Korea?

\footnotetext{
${ }^{82}$ Security Council Resolution: S/RES 2141 (2014).
}

83 (11-2-2). China and Russian Federation contra; Chad and Nigeria abstained. Three Permanent Members of the Council (France, United Kingdom and United States of America) voted in favour.

${ }^{84}$ COI Report A/HRC/25/CRP.1 (n 47) 370 [1225(a)]. The COI made it clear that 'in the light of the dire social and economic situation of the General population the Commission does not support sanctions imposed by the Security Council or introduced bilaterally that are targeted against the population or the economy as a whole'.

85 Sangwon Yoon and Sam Kim, 'North Korea Troops Ordered to Prepare for War’ Sydney Morning Herald (Sydney, 21 August 2015). On 27 August 2015 it was reported that, following a form of apology the military situation eased. 


\section{TEN PARALLELS}

\section{ACTION AND REACTION}

The demand of the barons for the agreement to a charter was a direct outcome of intolerable conduct on the part of King John. Abroad, he threatened to conduct expensive and dangerous wars in France. At home, he sought to raise taxes; offended the Church; and harmed trade and commerce. The Charter was not the product of a popular uprising, like the later Peasants' Revolt in England of 1381. In 1215, it was an uprising of the elite which, at last, responded to what it came to see as intolerable strains on the country and their own safety and rights. ${ }^{86}$

Witnesses before the public hearings of the COI told of their admiration for, and love of, Kim Il-sung. Kim Jong-il developed the nuclear arsenal; but he was generally cautious in his handling of the elite. Kim Jong-un, on the other hand, has disappointed the high expectations that accompanied his arrival. They had hoped for modernisation and liberalisation of the regime. He has proved violent in his disposal of enemies and oppressive in his dealings with most of the population.

Regime change in DPRK was never on the agenda of the COI, any more than military intervention in DPRK. That country is a member state of the United Nations which created the COI. Military action was not contemplated by the COI's mandate from the HRC and it had no power to propose it. However, ideas from without and within now challenge the situation in DPRK. In England in 1215, such challenges led to Magna Carta. Where it will lead in the case of DPRK is still unsure. That country was not obliged to join the United Nations. Yet, having done so, it is obliged to conform to universal human rights. They are expressed in the United Nation's Charter the UDHR and the treaties that have followed it. DPRK has itself ratified several of those treaties. ${ }^{87}$

Violence begets violence. Discontent growing from chronic food shortages, economic impoverishment, technological deprivations and other wrongs seem likely to produce demands in DPRK for radical reform. Hopefully, such reforms will follow the recommendations of the COI addressed to DPRK.$^{88}$ High in the list of those recommendations was the introduction of sound principles of governance; the implementation of restrictions on the exercise of public power; and the observance of due

\footnotetext{
${ }^{86}$ Theodore Frank Thomas Plucknett, A Concise History of the Common Law (n 6) 20.

${ }^{87}$ COI Report A/HRC/25/63, 6 [21].

${ }^{88}$ COI Report A/HRC/25/CRP.1 (n 47) 367-369 [1220(a) - (s)].
} 
process and basic rights for ordinary people in DPRK. Just as Magna Carta demanded centuries earlier in the case of King John's England.

\section{NOSTALGIA FEELINGS}

The demands expressed by the barons in MC1215 did not purport to express fresh insights. They were demands for the restoration of modes of governance that had existed during earlier reigns of the Norman and Saxon Kings of England. The Norman monarchs prided themselves on their strong centralised administration. To some extent, they drew legitimacy from nostalgic ideals that were traced back to the reign of the Anglo-Saxon King Edward: the only English monarch to have been named a saint ("St Edward the Confessor").

Whilst some witnesses before the COI clearly contemplated the entire replacement of the Kim Dynasty, others were themselves nostalgic for the founder of DPRK: Kim Il-sung. In part, that may have been the product of propaganda undamaged by current experience. In part, it might have derived from his leadership of the DPRK during the Korean War that ended in a stalemate. In part, it might be a result of the Soviet subsidisation of the DPRK economy before 1989 and the operation, at that time, of a comprehensive food rationing system. Whatever the reasons, discontent with, and even disrespect for, the regime of Kim Jong-un appear to be substantially higher than in the case of his predecessors as Supreme Leader of DPRK.

When King John died in England in 1216, the salvation of his dynasty was the conduct of his infant successor (Henry III) under a regency controlled by a gifted and loyal leader, the Earl of Pembroke. The closest parallel to this in DPRK appears to have been the uncle by marriage of the Supreme Leader (Jang Song-taek) who was speedily removed and executed. Reportedly, he favoured the adoption of Chinese-styled market reforms. His death removed an important actor in a potential process of transition. Regents have sometimes been viewed as rivals in history, and eliminated. Such appears to have been his fate.

\section{INSTITUTIONAL SOLUTIONS}

An important motivation for the barons who challenged John in 1215 was their objection to the deployment of royal power on the basis of the "whims" of the monarch. An achievement of the earlier Norman Kings (and indeed the late Anglo-Saxon monarchs) had been an improved system of clerks and processes of consultation ("counsel") involving a form of collective leadership. The absence, and infancy, of some of the 
succeeding monarchs tended to show that a regent, assisted by a council of magnates, could sometimes rule well. They could set a standard of administration that a single individual would find it difficult, unaided, to attain, simply because of the complexity of a country's public affairs.

The highest bishop in England, the Archbishop of Canterbury - a most powerful official at the time of King John - perceived the growing divorce between the person of the monarch and the concept of the English Crown. Thus, Stephen Langton (whom Pope Innocent III forced John to accept as Archbishop of Canterbury) expressed this notion well: ${ }^{89}$

"Loyalty was devotion, not to a man, but to a system of law and order which he believed to be a reflection of the law and order of the universe."

A distinctive feature of governance in DPRK is the concentration of supreme power in the personal hands of the Supreme Leader. As the COI pointed out in its report: $:^{90}$

"Apart from exercising power through his dominant role in the Party and the National Defence Commission, the Supreme Leader also acts as an autonomous decision-making institution. Former officials of the DPRK who provided testimony to the [COI] underlined that orders issued by the Supreme Leader are considered the highest type of normative command, overruling decisions of all other Parties or state institutions. The Constitution provides the normative underpinning by stipulating that the Supreme Leader ... "directs the overall affairs of state" [and] has the constitutional power to issue orders... superior... to, and abrogate, the decisions of any other organ of state."

According to testimony received by the COI, agencies had to submit detailed reports on the implementation of actions involving gross human rights violations to the Supreme Leader. ${ }^{91}$

Symbolising this concentration of power (and illustrating the personality cult built around the Supreme Leader) each member of the Kim Dynasty is repeatedly shown in media of all varieties, surrounded by

${ }^{89}$ Langton quoted in Powicke, Cambridge Medieval History, Vol VI, 219, cited in Theodore Frank Thomas Plucknett, A Concise History of the Common Law (n 6) 21.

${ }^{90}$ COI Report A/HRC/25/CRP.1 (n 47) 358 [1191] (footnotes omitted). ${ }^{91}$ Ibid. 
adulation and crowds charged with high emotion, sometimes bordering of hysteria. Moreover, each of the Kim leaders has toured the country giving "guidance". He is surrounded, by senior officials who are shown taking dutiful notes and recording his every word. This is what "guidance" involves. It equates to the itinerant conduct of medieval monarchs and reverence to their persons. It is not a feature of modern democratic governance, where the people, as electors, reserve to themselves a questioning and often sceptical attitude about leaders and would-be leaders that is healthy.

It was in 1215 that questioning spilt over into action by the barons in England that they presented their charter to John at Runnymede. Just as later their successors in England presented an indictment that led to the trial, conviction and beheading of Charles I in 1649; the protestation against the King"s lawless conduct that drove James II from the kingdom in 1688; the demand for a Bill of Rights that was granted in 1689 by William III and Mary; as a condition to their assuming the Crown; and the assertion of the parliamentary supremacy of the House of Commons agreed to by George V in the Parliament Act of 1911 that removed the last vestiges of the House of Lords' power to defeat or delay indefinitely the laws passed by the Commons. These were defining moments in English constitutionalism. But where are their equivalents in the constitutional narrative of DPRK?

\section{FROM GRANT TO RIGHT}

An important feature of the successive versions of Magna Carta was that they moved from concessions and grants, in the Coronation Oath of Henry II, and in the 1215 Charter of John, to the language of "given and granted" in the MC 1225 also and subsequent versions. Moreover, arguably, by referring to the "liberties" of "free men", later versions of MC 1215 also acknowledged the antecedent entitlements that the monarch was simply recognising (and promising to uphold) rather than "granting" (and thus entitled to withdraw). This was a shift from donation (out of the ruler's supreme powers) to acknowledgment of pre-existence, which the ruler agrees to respect as the price of continued kingship. It is an important distinction, Archbishop Langton's concept of the differentiating of the person of the ruler and the office that he or she holds.

Such a distinction may exist in the minds of some theoreticians of DPRK. But it appears nowhere in voice or writing. In the actuality of the way in which the country is governed, as described in the COI report, the differentiation is never observed in practice. Yet it is vital to good governance because of the inherent fallibility of all human beings. 
Monarchies still exist in the world. Britain and Australia are amongst them. However, the hereditary principle only survives in contemporary governance where the Langton differentiation is consistently observed. Then monarchy can be a convenient historical fiction of governance. However, such a differentiation is not observed in DPRK. This fact denies the citizens of DPRK a full measure of civic and political (including democratic) rights, promised in universal human rights law ${ }^{92}$ and observed in varying degrees in most modern nation states.

\section{LIBERTY - CONTROLLING DETENTION}

Some of the worst features of DPRK, described in the COI report, involve arbitrary conduct by agents of the state, including in the treatment of ordinary prisoners; the conditions of prison facilities; the extermination and murder of prisoners; the subjection of prisoners and detainees to torture, rape and grave violence; the enslavement and enforceable transfer of populations; and the lack of effective control over long-term detention not only of suspects but of their extended families.

Functionally, it was conduct of this type in the England of John that led to seizure, imprisonment and deprivation of rights without a judgment or control by the law (MC1215, c 39). By interposing the scrutiny of a decision upon such matters, by a third person official acting in accordance with the law, there is built into such actions a dual virtue. It is the provision of a second look at public actions by an outsider with a measure of dispassion and separation from the original actor. And careful examination of the challenged by reference to pre-existing rules that are discoverable, upheld and applied by people who know the law and are minded to keep it (MC1215, c 45).

According to the evidence received by the COI, these central features, reflected in the concessions extracted from King John in 1215, are not present, at least in many circumstances, in the DPRK today. Beyond the ordinary prisons, an extensive system of extrajudicial detention camps exist. They constitute a form of political prisons where detention, torture, executions and enforced disappearances are an ongoing feature of uncontrolled governmental power. ${ }^{93}$ The most basic feature of a civilised community is thus missing in DPRK. Security of one's person and

\footnotetext{
92 The right to participate in democracy in UN treaties was discussed in AttorneyGeneral (WA) v Marquet (2003) 217 CLR 545, 603 [174] ff; [2003] HCA 67: referring to art 25 of the International Covenant on Civil and Political Rights 1966.

${ }^{93}$ COI Report A/HRC/25/CRP.1 (n 47) 330-343 [1068]-[1130].
} 
significant possessions is not available, and certainly not from any official who is independent of the Supreme Leader and those immediately around him.

\section{FEUDALISM TO SONGBUN}

Successive versions of charters of liberties in England were extracted initially by unlikely champions. Those champions were themselves barons and other members of the nobility who were among the main beneficiaries of the feudal system. That system governed not only the land law that influenced the labour and status of the subjects. It also imposed on them duties of loyalty and service according to their rank at birth, which it was difficult to escape.

Into that world, where birth was destiny, was intruded Magna Carta, with its promises that went beyond the rights of the barons. The various chapters of MC1215 also spoke of the entitlements of the bishops and clergy of the Church; of the merchants and traders; and of foresters, knights and "free men". In this sense, Magna Carta was the beginning of the end of the universality of feudal fealty to a lord, imposed by birth and reinforced by oaths and other means of enforcement.

In DPRK, as the COI report shows, the assignment of the people to a state-specified social class (Songbun) continues to this day. It is the worst form of discrimination because of its universality and virtual inescapabilty. ${ }^{94}$

\section{AWARENESS OF THE PEOPLE}

When the barons extracted the promises from John, they did not leave it in the form of a Latin text on parchment. They provided, in terms, for the contents of the Charter to be drawn to the notice of the people of the kingdom. Specifically, they provided for the document to be read in the great cathedrals, where presumably, at least the educated subjects would know and understand and where recorders would translate for the common people. Word would get around. In the original Charter, sealed by John (MC1215) the barons also created a detailed mechanism to ensure that the promises would be kept. This was Ch.61 of the 1215 document ("the security clause"). It set out a procedure by which a Council of 25 persons (archbishops, barons and other notables) were delegated to monitor any royal evasion.

${ }^{94}$ Ibid 270-319 [846]-[1021]. 
The members of this extraordinary council were even authorised, in the event of evasion, to seize the King's castles, lands and possessions. Perhaps this is what persuaded Pope Innocent III to annul the document as "shameful, demeaning, injust", as well as "obtained under duress". 95 Although the security clause was dropped in all subsequent versions of Magna Carta, it showed an awareness on the part of the barons of the need for enforcement and collective leadership. Later, in 1258, a Council of 25 was again created to keep John's son, Henry III to his word. ${ }^{96}$ Eventually councils of such a kind would evolve into an increasingly insistent royal court and later still a Parliament.

The COI report on DPRK evidences deficiencies in governance of the same generic type that exercised the barons of England in 1215. Such is the status and power (including constitutional power) of the Supreme Leader in DPRK that there are no effective sanctions against him in the formal institutions of the country. Moreover, DPRK strictly controls access to knowledge and information. ${ }^{97}$ All forms of media are severely controlled by the governing party (Korean Workers' Party). Access to the internet is generally unavailable to the people. Any having illicit and forbidden access (including to popular television dramas from the ROK) are monitored by an intense surveillance system. If apprehended, they are severely punished. ${ }^{98}$ Freedom of expression is forbidden.

Despite repeated requests by the United Nations, the report of the COI has not been made available to the people of the DPRK, on the internet or intranet or otherwise. The COI itself, its members and officers of OHCHR were forbidden access to the people of DPRK. Since its report, the COI has been denied entry to explain its conclusions and findings, to justify its recommendations and answer criticisms. Recommendations for free access to the internet has been ignored. ${ }^{99}$ Copies of the COI report, in various formats, are smuggled into DPRK. But they are not read to the people from cathedrals or their local equivalents. It must be assumed that most of the people of DPRK have less knowledge today of the condemnations of the United Nations than the ordinary people in 1215 had of King John's Magna Carta.

\footnotetext{
95 Ibid 74 [265].

96 James Spigelman, 'Magna Carta in its Mediaeval Context' (n 15) 386.

${ }^{97}$ COI Report A/HRC/25/CRP.1 (n 47) 54-67 [197]-[239].

98 Ibid 385.

${ }^{99}$ COI Report A/HRC/25/CRP.1 (n 47) 45 [163] ff.
} 


\section{STABILITY AND BELLICOSITY}

In 1214, King John had tried to deflect unrest in England by engaging in a war against France. His forces were defeated in the Battle of Bouvines. This resulted in his loss of lands of the Duchy of Normandy, from where the English King's family had derived. The failure of this overseas distraction resulted in further attempts to raise monies to recapture the lost territory. King John continued his unpopular policies at home. This led to the now little remembered attempt to invite a French Prince to England to take the English Crown. Such overseas distractions only came to an end when King John fortuitously died. He was not the first, nor the last, ruler to attempt to overcome domestic disaffection by embracing a foreign diversion. The Korean War of 1950-1953, beginning with an attack by the armed forces of DPRK on the South, eventually resulted in the series of misfortunes that still haunt that country to this day.

In DPRK there remains deep animosity towards the United States of America, and it Allies, that fought under the United Nations flag in the Korean War. Although DPRK has long taught its people that the War was commenced by South Korean forces, supported by the United States, access to Soviet archives, now widely available and cited in the COI report, show that this was false. The war was initiated by Kim Il-sung. ${ }^{100}$ This notwithstanding, the stalemate that followed relief to DPRK, initiated by the People's Republic of China, certainly enlarged the hostility to the United States that continues to the present time. Even food aid, provided by the United States during the devastating famine ("arduous march") of 1996-8, was represented to the people of DPRK as "reparations" afforded by the Americans for their war crimes against DPRK. ${ }^{10}$

Hatred and mistrust run deep in DPRK. Following his election in December 2009, a personal letter was sent by President Obama to Kim Jong-il. It invited a new beginning to relations between the two countries. The President's open hand was slapped away. The personal envoy carrying his letter was not permitted to deliver it to the Supreme Leader. Instead, soon after, a ballistic missile test was conducted by DPRK that overflew Japan in the direction of the United States. Within a month of this event, a second nuclear test was conducted by DPRK. And a year later, a DPRK submarine torpedoed a ROK naval vessel, killing 56 young

\footnotetext{
${ }^{100}$ Ibid 24 [103] fn 28.

${ }^{101}$ Ibid 193 [633].
} 
ROK sailors. ${ }^{102}$ On the face of things, this constitutes the modern equivalent of King John gnawing branches. The appeal now is not to a Party or philosopher or a supposedly superior form of governance of society. It is to nuclear weapons, missiles and submarines.

\section{INTRACTABILITY AND ACTION}

At the end of 1215, with Magna Carta annulled by the Pope, King John's position had been restored to the condition it was in prior to the sealing of the instrument. However, John continued to face many challenges, including the imported alternative prince from France. Only his human mortality terminated the dangers of an uncertain outcome involving invasion and open rebellion. Only the wise regency that followed, and a revised Magna Carta, confirmed and reconfirmed, changed the direction of English history. It did so in terms that retained the external trappings (and some powers) of the King. Whilst conceding the central idea of MC1215 that the King's powers were subject to limits and separate to some degree from his person. That point has not yet been reached in DPRK.

\section{INTERNAL SOLUTIONS}

There is one final lesson for the Korean Peninsula today from the struggle of King John with Magna Carta in 1215. It is a lesson that goes beyond the text or even the context of that document. It arises from the situation faced in 1215 and the way the dangers of that time were avoided and addressed.

In the end, solutions were found. But they were found within England itself. The immediate solutions (a wise regency; confirmation of a modified Magna Carta; and reconfirmation by the same by later kings) was by no means the end of the constitutional story. That story continued to evolve during later centuries. Subsequent chapters of the story were added as the influence of the idea of limited governmental power expanded to include England's colonies former colonies and dominions beyond the seas. Eventually, principles of limited government, the rule of law and respect for fundamental human dignity and rights spread far beyond the English-speaking countries, with their memories of Magna Carta. Through the proclamation of the Four Freedoms during the Second

102 Victor Cha, The Impossible State: North Korea, Past and Future (New York, Harper Collins 2012) 10. 
World War, they spread to the whole planet: even beyond countries of similar constitutional background. In truth, today, the United Nations Charter is a contemporary global reflection of the central idea of Magna Carta. That is the idea of limited power in, and between, the nations and rulers. This idea now extends to all the countries of the world.

That extension has come only just in time. Without it, it would not have been possible for independent nation states, however powerful, to protect the planet, from the ravages of war; the derogations of universal rights, the defiance of the rule of law and the debasement justice; the oppression of colonialism, apartheid and foreign domination; the dangers of HIV/AIDS, ebola, malaria and other diseases; the creeping risks of climate change; and the horrors of nuclear proliferation, accident and destruction.

Human history advances by human endeavour. Lodged somewhere in the DNA of human beings is a tendency that favours rationality, intelligibility and justice. That is why humans have created the United Nations. It is why they have created the Human Rights Council and the Office for the High Commissioner for Human Rights. It is why they established a Commission of Inquiry and a Special Rapporteur on DPRK. It is why the global community must now ensure that the recommendations of these office-holders are known, considered and followed up with action.

It is the responsibility of all nations and of human beings everywhere to protect the people of DPRK from crimes against humanity. We must not default in that responsibility. In 2015 the world, through the United Nations, must advance the idea of control over rulers and accountability for crimes against the people. One historic source for that grand idea was the event that happened at Runnymede in England in June 1215. 